\title{
Sistem Pendukung Keputusan Produk Patiseri Terbaik dengan Metode Profile Matching
}

\author{
Mauldy Laya, \\ Teknik Informatika \\ Jurusan Teknik Informatika dan Komputer \\ Politeknik Negeri Jakarta \\ Depok, Indonesia \\ dylaya@gmail.com
}

\author{
Luthfi Zainnur \\ Teknik Informatika \\ Jurusan Teknik Informatika dan Komputer \\ Politeknik Negeri Jakarta \\ Depok, Indonesia \\ luthfi.zainnur@gmail.com
}

Diterima: 10 September 2015. Disetujui: 15 Oktober 2015. Dipublikasikan: November 2015

\begin{abstract}
Abstrak-Perkembangan teknologi yang melesat saat kini menghadirkan satu kemudahan dalam kehidupan manusia. Untuk memudahkan dan meningkatkan sistem produksi terutama pada industri rumahan patiseri, maka diperlukan sebuah sistem pendukung keputusan yang dapat membantu pihak industri rumahan tersebut dalam memutuskan jumlah produksi berdasarkan jumlah produk yang laku, terbaik, dan terpopuler di masyarakat. Dengan menggunakan sebuah kuesioner untuk mengetahui produk terbaik dan terpopuler di masyarakat, serta menggunakan metode profile matching untuk membantu proses penghitungan seluruh data jawaban kuesioner sehingga menghasilkan peringkat dari produk-produk yang telah dipilih oleh pelanggan melaluiproses pengisian kuesioner. Profile Matching adalah sebuah mekanisme pengambilan keputusan dengan mengasumsikan bahwa terdapat tingkat variabel prediktor yang ideal yang harus dipenuhi oleh subyek yang diteliti, bukannya tingkat minimal yang harus dipenuhi atau dilewati. Hasil yang dicapai dalam perhitungan menggunakan metode profile matching ini adalah sebuah nilai yang akan diurutkan dari yang terbesar hingga terkecil dan akan menghasilkan sebuah urutan peringkat. Hasil perbandingan perhitungan secara manual dan otomatis melalui aplikasi didapat hasil yang sama sehingga dapat mempercepat proses apabila digunakan aplikasi yang telah dibuat.
\end{abstract}

Kata kunci: Industri rumahan, patiseri, profile matching, sistem pendukung keputusan

\section{PENDAHULUAN}

Seiring dengan perkembangan teknologi yang semakin maju, kebutuhan masyarakat akan teknologi informasi juga terus meningkat. Pada saat ini teknologi informasi sangat membantu manusia dalam menyelesaikan berbagai persoalan hidup, terutama dalam sektor industri. Industri rumahan merupakan salah satu industri yang sedang berkembang pesat di Indonesia, berbagai usaha baik produk maupun jasa tercipta. Industri rumahan memerlukan sebuah umpan balik dari masyarakat untuk kemajuan usaha kedepannya. Ariesty Cake merupakan salah satu industri rumahan yang bergerak di bidang produksi kue dan roti.Industri rumahan ini berkembang pesat di daerah Sukabumi dan telah memiliki beberapa agen pemasaran di kota tersebut.

Ariesty Cake ingin lebih memuaskan hati konsumen dengan meningkatkan kualitas produk produk yang mereka miliki. Maka dari itu untuk membantu industri ini semakin maju diperlukan sebuah sistem pendukung keputusan yang akan membantu kemajuan industri rumahan dalam memaksimalkan kualitas produksi patiseri mereka serta meningkatkan produksi sesuai dengan keadaan pasar berdasarkan produk terpopuler saat itu sehingga dapat memuaskan konsumen.

Metode profile matching atau pencocokan profil adalah metode yang sering digunakan sebagai mekanisme dalam pengambilan keputusan dengan mengasumsikan bahwa terdapat tingkat variabel prediktor yang ideal yang harus dipenuhi oleh subyek yang diteliti[1]. Beberapa kasus telah diteliti dengan menggunakan metode ini yaitu dalam pemberian bonus karyawan[2],menentukan siswa berprestasi[3], dan seleksi karyawan untuk jabatan tertentu[4].

\section{METODE PENELITIAN}

Hal pertama dalam penggunaan metode profile matching adalah penentuan aspek apa sajakah yang akan digunakan dalam penghitungan penentuan peringkat setiap produk.

Setelah aspek yang akan dinilai telah ditentukan maka tahapan selanjutnya adalah penentuan sub aspek dari setiap aspek yang akan dinilai. Sub aspek tersebut akan dikelompokkan menjadi faktor utama dan faktor sekunder. Setelah itu setiap sub aspek akan diberikan nilai standar minimal. Selanjutnya tahapan perhitungan 
pencarian peringkat dalam profile matching adalah sebagai berikut [7]:

a) Mencari nilai GAP dan konversikan ke dalam nilai bobot. Nilai GAP didapat dari hasil pengurangan nilai yang telah diberikan user yang dikurangi nilai standar minimal yang telah ditentukan di setiap sub aspek. Selanjutnya nilai GAP yang di dapat akan di konversikan ke dalam nilai bobot. Menghitung nilai rata - rata faktor utama dan faktor pendukung dari setiap aspek.

b) Menghitung nilai rata - rata faktor utama dan faktor pendukung dari setiap aspek.

c) Perhitungan nilai total.

Dari hasil perhitungan dari tiap aspek di atas kemudian dihitung nilai total berdasarkan presentasi dari core dan secondary yang diperkirakan berpengaruh terhadap penilaian tiap tiap profile.

d) Perhitungan penentuan peringkat.

Hasil akhir dari perhitungan dengan menggunakan metode profilematching adalah sebuah peringkat.

Untuk realisasi, sistem pendukung keputusan dibuat menjadi aplikasi berbasis web yang pada sisi klien mengunakan teknologi responsif agar dapat menyesuaikan dengan ukuran layar[5]. Pada sisi server digunakan teknologi framework laravel yang cukup populer saat ini dengan dukungan pustaka yang memudahkan pembuatan aplikasi web[6]. Pembuatan aplikasi dengan metode daur hidup pengembangan sistem yang terdiri atas analisa, desain, implementasi dan pengujian.

\section{HASIL DAN PEMBAHASAN}

Aplikasi ini terdapat dua aktor, yaitu admin dan user, masing-masing aktor memiliki fungsionalitas masing-masing. Aktor admin dapat melakukan login ke dalam sistem serta melakukan pengelolaan kuesioner, sedangkan user hanya dapat melakukan pengisian kuesioner secara online maupun offline. Selanjutnya ketika user melakukan kuesioner secara offline, maka admin akan menginputkan ke dalam sistem.Use case diagram untuk aplikasi ini dapat dilihat pada gambar 1 dibawah ini:

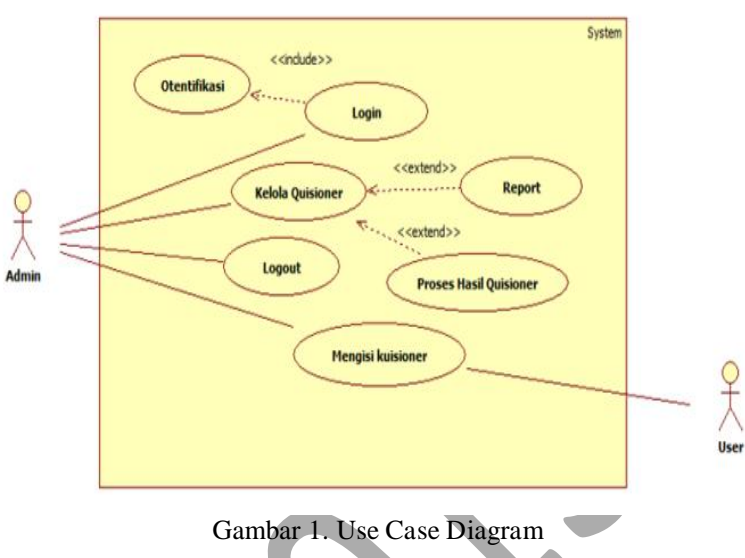

Gambar 2memperlihatkan ketika user melakukan pengisian kuesioner secara online. Terlihat bahwa setelah melakukan pengisian kuesioner berhasil maka sistem selanjutnya akan memunculkan halaman peringkat terbaru dari produk terbaik saat ini. Pengisian kuesioner akan diulangi apabila terjadi kesalahan pada saat penyimpanan data.

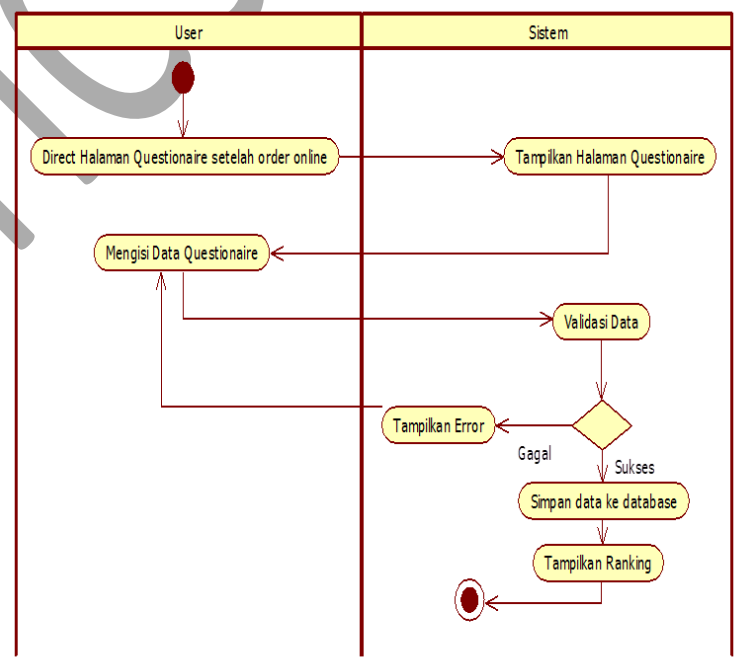

Gambar 2. ActivityDiagramUser Mengisi Kuesioner

Dalam melakukan input kuesioner pelanggan, seorang admin harus login terlebih dahulu. Selanjutnya setiap input akan dilakukan validasi oleh sistem, apabila sukses akan disimpan dan sebaliknya akan ada pemberitahuan kesalahan. 


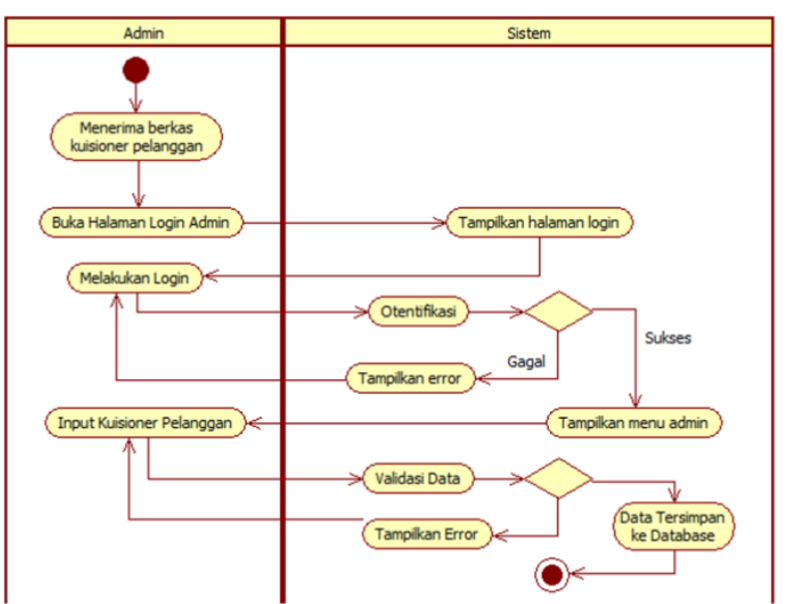

Gambar 3.Activity Diagram Admin Mengisi Kuesioner

Selanjutnya adalah diagram aktivitas untuk mengelola seluruh kuesioner dan proses untuk mengetahui produk terbaik. Pada halaman admin terdapat menu untuk melakukan proses perangkingan produk terbaru dengan mengambil data dari yang telah dimasukkan sebelumnya. Setelah data terlihat laporannya dalam bentuk file pdf dan dapat dicetak dokumentasi.

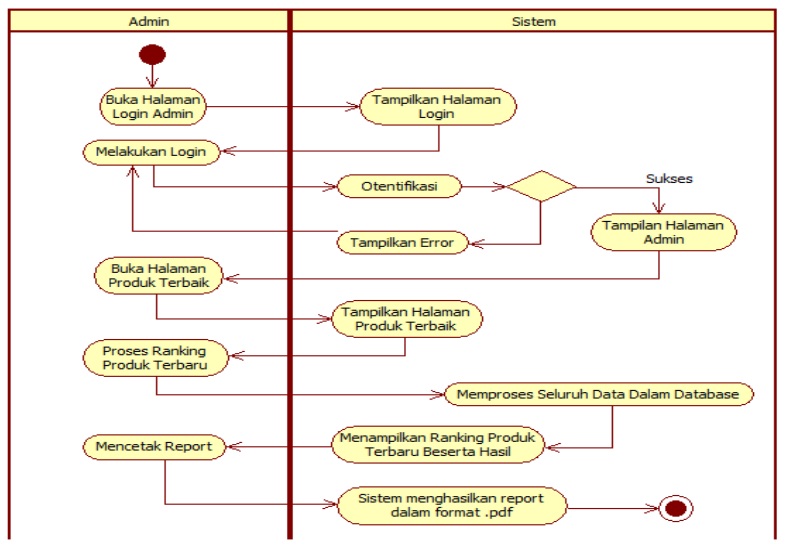

Gambar 4. Diagram Activity untuk proses mencari peringkat

Ada 7 kelas yang dibuat untuk aplikasi ini, yaitu Main, Login, InputKuesioner, MengelolaHasilKuesioner, KoneksiBasisData, Rangking, dan Jawaban. Gambar diagram kelas dapat dilihat pada gambar berikut ini:

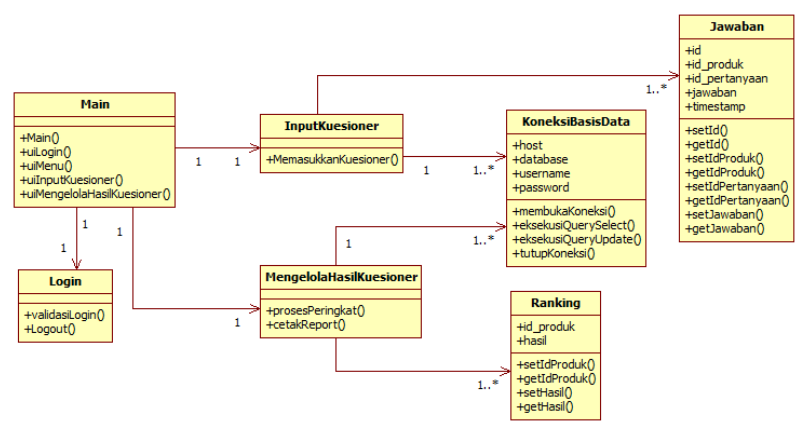

Gambar 5. Class Diagram

Dalam penentuan metode profilematching, yang pertama kali dilakukan adalah menentukan kriteria serta sub kriteria yang akan digunakan sebagai parameter penghitungan dalam profile matching [6] setelah itu setiap sub aspek akan ditentukan nilainya yang di mana nantinya nilai tersebut akan digunakan untuk mencari nilai gap yang diperlukan dalam penghitungan profilematehing.

\section{TABEL 1. ASPEK DAN STANDAR NILAI}

\begin{tabular}{ccccc}
\hline No & Kriteria & Sub Kriteria & Nilai (1-3) & Kelompok \\
\hline \multirow{4}{*}{1} & Aspek Citarasa & Rasa & 2 & CF \\
\cline { 3 - 5 } & & Aroma & 2 & CF \\
\cline { 3 - 5 } & & Tekstur & 1 & SF \\
\hline \multirow{2}{*}{ Aspek Penampilan } & Design & 1 & SF \\
\cline { 3 - 5 } & Komposisi & 2 & CF \\
\cline { 2 - 4 } & & Harga & 1 & SF \\
\cline { 2 - 4 } & & Garnish & 2 & CF \\
\cline { 2 - 4 } & & & &
\end{tabular}

Keterangan:

$\mathrm{CF}=$ Core Factor $/$ faktor utama

$\mathrm{SF}=$ Secondary Factor $/$ faktor pendukung.

Standar penilaian menggunakan nilai antara $1-3$ yang di mana dalam kuesioner angka satu (1) mewakili untuk tidak puas, angka dua (2) mewakili puas, danangka tiga (3) mewakili sangat puas. Pertanyaan yang dapat dikembangkan dari sub aspek dapat dijabarkan Tabel 2.

TABEL 2. TABEL PERTANYAAN

\begin{tabular}{cl}
\hline No & \multicolumn{1}{c}{ Pertanyaan } \\
\hline 1 & Bagaimanakah penilaian rasa produk ini menurut anda? \\
\hline 2 & Bagaimanakah penilaian aroma produk ini menurut anda? \\
\hline 3 & Bagaimanakah penilaian tekstur produk ini menurut anda? \\
\hline 4 & Bagaimanakah penilaian design produk ini menurut anda? \\
\hline 5 & $\begin{array}{l}\text { Bagaimanakah penilaian komposisi produk ini menurut } \\
\text { anda? }\end{array}$ \\
\hline 6 & $\begin{array}{l}\text { Bagaimanakah penilaian anda tentang harga untuk produk } \\
\text { ini menurut anda? }\end{array}$ \\
\hline 7 & $\begin{array}{l}\text { Bagaimanakah penilaian anda tentang pemilihan garnish } \\
\text { untuk produk ini menurut anda? }\end{array}$ \\
\hline
\end{tabular}


Di dalam perhitungan menggunakan metode profile matching, selain nilai dari setiap sub aspek, nilai persen untuk menghitung nilai total setiap aspek sudah ditentukan, yaitu untuk sub aspek yang memiliki corefactor maka akan memiliki persen sebanyak $60 \%$, sedangkan untuk sub aspek yang memiliki secondaryfactor maka akan memiliki persen sebanyak $40 \%$. Untuk penghitungan peringkat, setiap aspek memiliki persen yang telah ditentukan yaitu untuk aspek cita rasa memiliki persen sebanyak 60\% sedangkan untuk aspek penampilan memiliki persen sebanyak $40 \%$. Sebuah contoh data perhitungan dengan menggunakan profile matching telihat pada tabel berikut.

\begin{tabular}{|c|c|c|c|c|}
\hline No & $\begin{array}{c}\text { Id } \\
\text { Produk }\end{array}$ & $\begin{array}{l}\text { Nama } \\
\text { Produk }\end{array}$ & Id Pertanyaan & Jawaban \\
\hline \multirow[t]{7}{*}{1} & 10002 & Red Velvet & 11 (Rasa) & 1 \\
\hline & & & 12 (Aroma) & 2 \\
\hline & & & 13 (Tekstur) & 3 \\
\hline & & & 14 (Design) & 2 \\
\hline & & & 15 (Komposisi) & 1 \\
\hline & & & 16 (Harga) & \\
\hline & & & 17 (Garnish) & \\
\hline \multirow[t]{6}{*}{2} & 20002 & Roti Sosis & 11 (Rasa) & 3 \\
\hline & & & 12 (Aroma) & \\
\hline & & & 13 (Tekstur) & \\
\hline & & & (1) & \\
\hline & & & $15(\mathrm{~K}$ & \\
\hline & & $\Omega$ & 17 (Garnish) & 1 \\
\hline
\end{tabular}

Nilai gap serta konversi nilai bobot setiap sub kriteria dapat dilihat pada tabel 4. Sebagai sample untuk dua produk.

TABEL 4. KONVERSI NILAI BOBOT SETIAP SUB KRITERIA

\begin{tabular}{|c|c|c|c|c|}
\hline No Id Produk & Jawaban & Nilai & GAP & Bobot \\
\hline \multirow[t]{7}{*}{1} & 1 & 2 & -1 & 3,5 \\
\hline & 2 & 2 & 0 & 4 \\
\hline & 3 & 1 & 2 & 5 \\
\hline & 2 & 1 & 1 & 4,5 \\
\hline & 1 & 2 & -1 & 3,5 \\
\hline & 2 & 1 & 1 & 4,5 \\
\hline & 3 & 2 & 1 & 4,5 \\
\hline 20002 & 3 & 2 & 1 & 4,5 \\
\hline
\end{tabular}

\begin{tabular}{ccccc}
\hline & 2 & 2 & 0 & 4 \\
\hline & 1 & 1 & 0 & 4 \\
\hline 2 & 1 & 1 & 4,5 \\
\hline 3 & 2 & 1 & 4,5 \\
\hline 2 & 1 & 1 & 4,5 \\
\hline 1 & 2 & -1 & 3,5 \\
\hline
\end{tabular}

Langkah kedua perhitungan dan pengelompokan core factor (NCF) dan secondary factor (NSF).

TABEL 5. TABEL PENGELOMPOKAN NCF DAN NSF ASPEK CITA RASA

\begin{tabular}{|c|c|c|c|}
\hline Id Produk & Aspek & $\mathrm{NCF}$ & NSF \\
\hline 10002 & 3,5 & 3,75 & 4,5 \\
\hline 20002 & 4,5 & 4,25 & 4 \\
\hline
\end{tabular}

Rumus:

$N C F=\frac{\sum C F}{N}=\frac{(A+B)}{N}$ dan $N S F=\frac{\sum S F}{N}=\frac{C}{N}$

TABEL 6. TABEL PENGELOMPOKAN NCF DAN NSF ASPEK PENAMPILAN

\begin{tabular}{ccccccc}
\hline Id Produk & \multicolumn{4}{c}{ Aspek Penampilan } & NCF & NSF \\
\cline { 2 - 5 } & A & B & C & D & & \\
\hline 10002 & 4,5 & 3,5 & 4,5 & 4,5 & 4 & 4.5 \\
\hline 20002 & 4,5 & 4,5 & 4,5 & 3,5 & 4 & 4.5 \\
\hline
\end{tabular}

Rumus:

$N C F=\frac{\sum C F}{N}=\frac{(B+D)}{N}$ dan $N S F=\frac{\sum S F}{N}=\frac{(A+C)}{N}$

Keterangan:

Citarasa: $\mathrm{A}=$ Rasa (11) $\| \mathrm{B}=$ Aroma (12) $\| \mathrm{C}=$ Tekstur (13)

Penampilan: A = Design (14) $\| \mathrm{B}=$ Komposisi (15)

$\| \mathrm{C}=$ Harga (16) $\| \mathrm{D}=$ Garnish (17)

$\mathrm{NCF}=$ Pengelompokan Core Factor

NSF $=$ Pengelompokan Secondary Factor

$\mathrm{N}$ = Jumlah data

Langkah ketiga melakukan nilai total setiap aspek.

TABEL 7. NILAI TOTAL ASPEK CITA RASA

\begin{tabular}{|c|c|c|c|c|c|c|}
\hline \multirow[t]{2}{*}{ Id Produk } & \multicolumn{3}{|c|}{ Aspek Citarasa } & \multirow[t]{2}{*}{$\mathrm{NCF}$} & \multirow[t]{2}{*}{ NSF } & \multirow[t]{2}{*}{ N1 } \\
\hline & $\bar{A}$ & B & $\mathrm{C}$ & & & \\
\hline 10002 & 3,5 & 4 & 4,5 & 3,75 & 4,5 & 4,05 \\
\hline 20002 & 4,5 & 4 & 4 & 4,25 & 4 & 4,15 \\
\hline
\end{tabular}


TABEL 8. NILAI TOTAL ASPEK PENAMPILAN

\begin{tabular}{cccccccc}
\hline Id Produk & \multicolumn{4}{c}{ Aspek Penampilan } & NCF & NSF & N2 \\
\cline { 2 - 5 } & A & B & C & D & & & \\
\hline 10002 & 4,5 & 3,5 & 4,5 & 4,5 & 4 & 4.5 & 4,2 \\
\hline 20002 & 4,5 & 4,5 & 4,5 & 3,5 & 4 & 4.5 & 4,2 \\
\hline
\end{tabular}

Rumus:

$N(12)=(60 \% * N C F)+(40 \% * N S F)$

Keterangan:

$\mathrm{N}\left(\begin{array}{ll}1 & 2\end{array}\right)=$ Nilai rata - rata dari setiap aspek setiap produk.

Langkah keempat perhitungan penentuan peringkat

TABEL 9. PENENTUAN PERINGKAT

\begin{tabular}{cccccc}
\hline No & Id Produk & Nama Produk & N1 & N2 & Hasi \\
\hline 1 & 10002 & Red Velvet & 4,05 & 4,2 & 4,11 \\
\hline 2 & 20002 & Roti Sosis & 4,15 & 4,2 & 4,17 \\
\hline \multicolumn{5}{c}{ Rumus: } \\
\multicolumn{5}{c}{$H a=(60 \% * N 1)+(40 \% * N 2)$} \\
\hline No & Id Produk & Nama Produk & Hasil \\
\hline 1 & 20002 & Roti Sosis & 4,17 \\
\hline 2 & 10002 & Red Velvet & 4,11 \\
\hline
\end{tabular}

Gambaran urutan proses dalam melakukan profile matching di atas pada aplikasi yang telah dibuat dapat dilihatpada flowchart gambar 6.

Tampilan aplikasi dapat dilihat pada gambar berikut, dimana terlihat halaman kuesioner dan halaman proses peringkat.

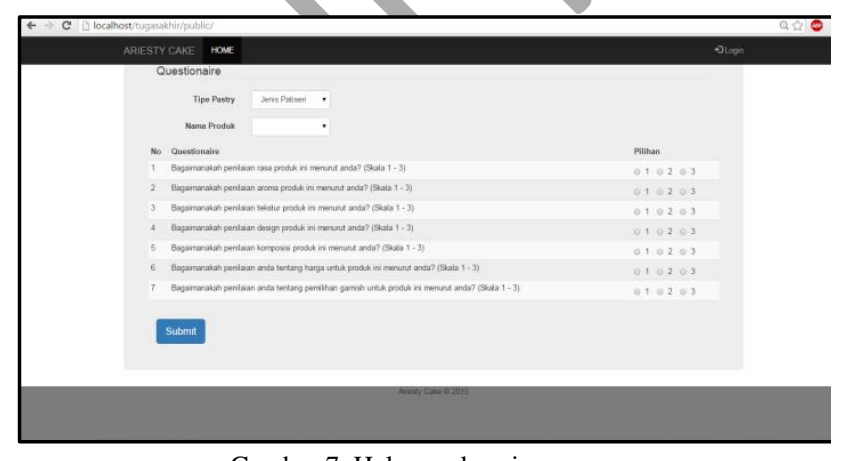

Gambar 7. Halaman kuesioner

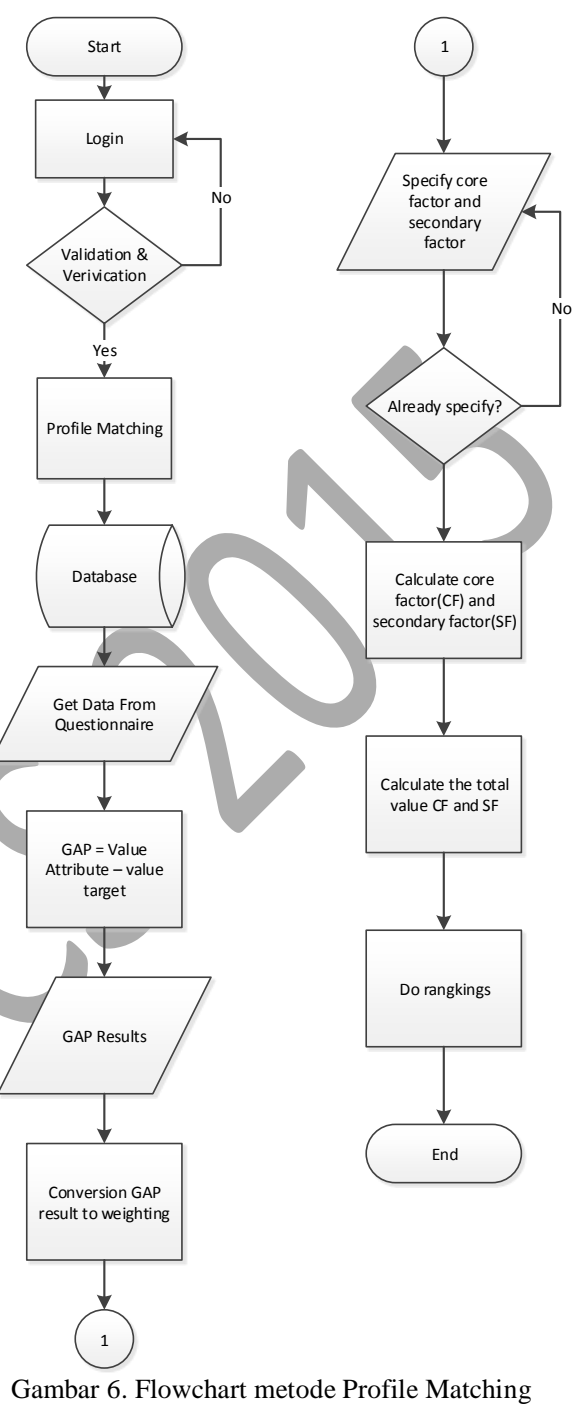

Gambar 6. Flowchart metode Profile Matching

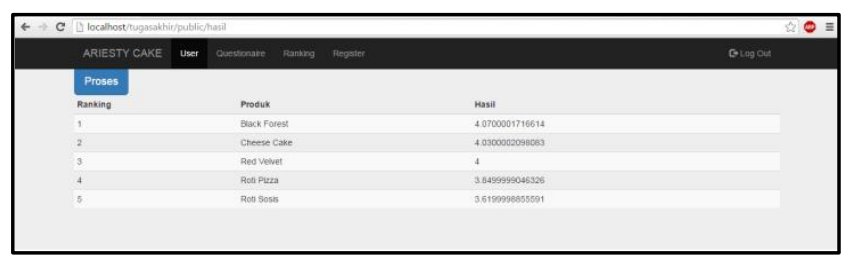

Gambar8. Halaman proses peringkat 


\section{IV.KESIMPULAN}

Sistem pendukung keputusan yang telah dibuat dapat memberikan informasi yang berguna untuk meningkatkan sistem produksi patiseri di Ariesty Cake. Sistem melakukan peringkat produk dengan menggunakan kuesioner dan data diolah menggunakan metode profile matching sehingga menghasilkan peringkat dari setiap produk dan terlihat produk-produk yang saat ini sedang disukai masyarakat. Hasil perhitungan secara manual dan otomatis melalui aplikasi didapat hasil yang sama sehingga dapat mempercepat proses apabila digunakan aplikasi.

Pengembangan selanjutnya dapat membuat aplikasi ini menjadi lebih dinamis dimana setiap aspek dan sub aspek dapat diatur dan ditentukan sesuai dengan kebutuhan industri. Penambahan modul point of sale serta modul suply chain management sehingga membuat hasil produksi menjadi lebih akurat dan dapat terlacak stok serta biayanya.

\section{DAFTAR PUSTAKA}

[1] Kusrini. Konsep Dan Aplikasi Sistem Pendukung Keputusan. Yogyakarta: Andi. 2007.

[2] Sherly, Nina. Penerapan Metode Profile Matching Dalam Sistem Pendukung Keputusan Pemberian Bonus Karyawan (Studi Kasus: Pt. Sanghyang Seri Persero). Majalah Ilmiah Informasi dan Teknologi Ilmiah. Volume 1: hal 42 - 47. 2013.

[3] Febri, Sugiarto Pratama. Sistem Pendukung Keputusan Menentukan Siswa Berprestasi Pada SMA Institut Indonesia Semarang menggunakan Metode Profile Matching. Skripsi. Tidak Dipublikasikan. Semarang: Universitas Dian Nuswantoro. 2014

[4] Bambang, Haris Nur. Sistem Pendukung Keputusan Seleksi Karyawan untuk Jabatan Tertentu Menggunakan Metode Profile Matching. Surabaya : STIKOM. Surabaya. 2007.

[5] Alatas, Husein. Responsive Web Design dengan PHP dan Bootstrap. Yogyakarta: Lokomedia. 2013.

Aminudin. Cara Efektif Belajar Framework Laravel. Yogyakarta: Lokomedia. 2015

[6] Yi Zhao, Zhong Li, Xia Wang, Wolfgang A. Halang,"Decisionsupport in e-business based on assessing similarities between ontologies.", Knowledge-Based Systems, Volume 32, August 2012, Pages 47-55

[7] Arjan Jeckmans; Qiang Tang; Pieter Hartel, "Privacy-preserving profilematching using the social graph.”, 2011 International Conference on Computational Aspects of Social Networks (CASoN), 2011, Pages: 42 - 47 